\title{
Systematic Review: Is Intradiscal Injection of Bone Marrow Concentrate for Lumbar Disc Degeneration Effective?
}

\author{
Takashi Hirase ${ }^{1}$, Robert A. Jack II ${ }^{1}$, Kyle R. Sochacki ${ }^{1}$, Joshua D. Harris ${ }^{1}$, Bradley K. Weiner ${ }^{1}$
}

1. Orthopedics and Sports Medicine, Houston Methodist Hospital, Houston, USA

Corresponding author: Takashi Hirase, thirase@houstonmethodist.org

\begin{abstract}
Current studies evaluating the outcomes of an intradiscal injection of bone marrow concentrate (BMC) for lumbar disc degeneration are limited. The purpose of this review was to determine if an intradiscal injection of BMC for lumbar disc degeneration results in a statistically significant improvement in clinical outcomes. A systematic review was performed using Preferred Reporting Items for Systematic Reviews and Meta-Analyses (PRISMA) guidelines. Levels I-IV investigations of intradiscal BMC injections in symptomatic lumbar disc degeneration were included in the analysis. Modified Coleman Methodology Scores (MCMS) were used to analyze study methodological quality. Only outcome measurements used by more than $50 \%$ of included studies, with a minimum follow-up of 12 months, were eligible for final data analysis. Pre-injection and post-injection visual analog scale (VAS) and Oswestry disability index (ODI) were compared using twosample Z-tests. Seven articles ( 97 subjects ( 47 males, 38 females, 12 unspecified), mean age $33.9 \pm 14.3$ years, mean follow-up $44.4 \pm 25.4$ months) were analyzed. Six articles were level IV evidence and one article was level II. Mean MCMS was $56.6 \pm 9.1$. All subjects received single injections into the nucleus pulposus of one or more affected discs. VAS (66.0 mm to $20.9 \mathrm{~mm}$; p<0.001) and ODI ( 44.4 to $19.1 ; \mathrm{p}<0.001$ ) significantly improved following the intradiscal BMC injection. One patient (1.0\%) experienced herniated nucleus pulposus (HNP) following treatment. No other complications or re-injections were reported. In conclusion, despite our skepticism regarding the efficacy of the procedure, intradiscal injection of BMC for lumbar disc degeneration resulted in statistically significant improvement in VAS and ODI with low re-injection and complication rates in the studies assessed. Given that this study is limited to level IV evidence, the findings suggest that further randomized controlled studies may be worthwhile to evaluate the true efficacy of this treatment.
\end{abstract}

Received 06/27/2020 Review began 07/01/2020 Review ended 07/01/2020 Published 07/07/2020

๑) Copyright 2020 Hirase et al. This is an open access article distributed under the terms of the Creative Commons Attribution License CC-BY 4.0., which permits unrestricted use, distribution, and reproduction in any medium, provided the original author and source are credited.
Categories: Pain Management, Neurosurgery, Orthopedics

Keywords: bone marrow concentrate, lumbar disc degeneration, degenerative disc disease, intradiscal injection

\section{Introduction And Background}

Lumbar disc degeneration is one of the most common causes of disability in the United States, felt to account for (directly or indirectly) over $40 \%$ of chronic low back pain [1-2]. Though intervertebral disc degeneration is usually an asymptomatic, normal, age-related phenomenon, it is recognized that it may be a source of acute or chronic low back pain [3-4]. A combination of various medical and physical treatments are often successful in treating such pain. However, over $10 \%$ of these patients are refractory to these nonsurgical measures, occasionally requiring costly surgical procedures and contributing to public health concerns due to rising costs and health care use [5-6]. Current treatment options are limited despite the high prevalence and morbidity associated with disc degeneration. A combination of non-surgical measures, such as bed rest, non-steroidal anti-inflammatory drugs (NSAIDs), physical therapy, and analgesic injections, is a common treatment of early disease that has been shown to decrease symptoms but not slow down the potential progression of the disease $[7-10]$. Surgical procedures, such as spinal fusion, are often used for treating refractory disease but are invasive, expensive, and have high rates of postoperative complications $[11-15]$.

In recent years, biological therapies have become increasingly popular, and the injection of bone marrow concentrate (BMC) into the intervertebral disc has emerged as a minimally invasive treatment option for patients unresponsive to non-invasive measures [16]. Mesenchymal stem cells comprise $0.01 \%-0.02 \%$ of $\mathrm{BMC}$ and have the ability to proliferate and differentiate into a variety of cell lineages, including cells within the nucleus pulposus and chondrocytes that make up the intervertebral discs [17-18]. MSCs have been shown to be successfully acquired in vivo from various sources, including bone marrow aspirate, adipose cells, and umbilical cord fragments [19-22]. Several animal studies have shown that the transplantation of 0.5 to 6 million MSCs within the nucleus pulposus via percutaneous or open procedures activates the further proliferation of nucleus pulposus cells while also stimulating the production of extracellular matrix proteins and collagen, which are vital to the supportive function of the intervertebral discs [19-22].

Though there are promising results among animal studies, current human studies evaluating the outcomes of intradiscal BMC injections in lumbar disc degeneration are mostly limited to small case reports and 
retrospective studies. Furthermore, there are currently no studies that investigate the clinical relevance of these outcomes. Thus, the purpose of this investigation was to determine if the intradiscal injection of BMC for lumbar disc degeneration results in a statistically significant improvement in clinical outcomes.

\section{Review}

\section{Methods}

A systematic review was registered with the International Prospective Register of Systematic Reviews (PROSPERO) on October 26, 2017 (Registration \# CRD42017075842). Preferred Reporting Items for Systematic Reviews and Meta-analyses (PRISMA) guidelines were followed and a checklist created [23]. Eligible studies consisted of levels I-IV (via Oxford Centre for Evidence-Based Medicine (CEBM)) therapeutic studies that investigated the outcomes of intradiscal BMC injections for lumbar disc degeneration among adult human patients [24]. The diagnosis was made in each included study based on a combination of history, physical examination, and radiographs, including magnetic resonance imaging (MRI). Pfirrmann grade, modified Pfirrmann score, decreased fluid density, the presence of intervertebral regressive degeneration, and/or the presence of a posterior disc bulge were used to classify the severity of degeneration included in each study. Studies that included other etiologies of back pain were excluded. Cadaveric studies, basic science and animal studies, diagnostic studies, economic studies, prognostic studies, level V evidence expert opinion, letters to editors, and review articles were also excluded. Studies published in non-English languages were eligible for inclusion (none were identified in search conduct). In cases of different studies with duplicate subject populations, the study with the longer follow-up, higher level of evidence, greater number of subjects, or greater clarity of methods and results was included. The authors conducted separate searches of the following medical databases: MEDLINE, Web of Science, and Cochrane Central Register of Controlled Trials databases. Under the PROSPERO registration, similar prior systematic reviews and metaanalyses were sought and none were identified. The searches were performed on April 24, 2020. The search terms used were "mesenchymal stem cells", "bone marrow concentrate", "degenerative disc", "spine”, and "injection." The search results were reviewed for duplicates and the inclusion criteria determined the articles that were included in the final analysis (Figure 1).

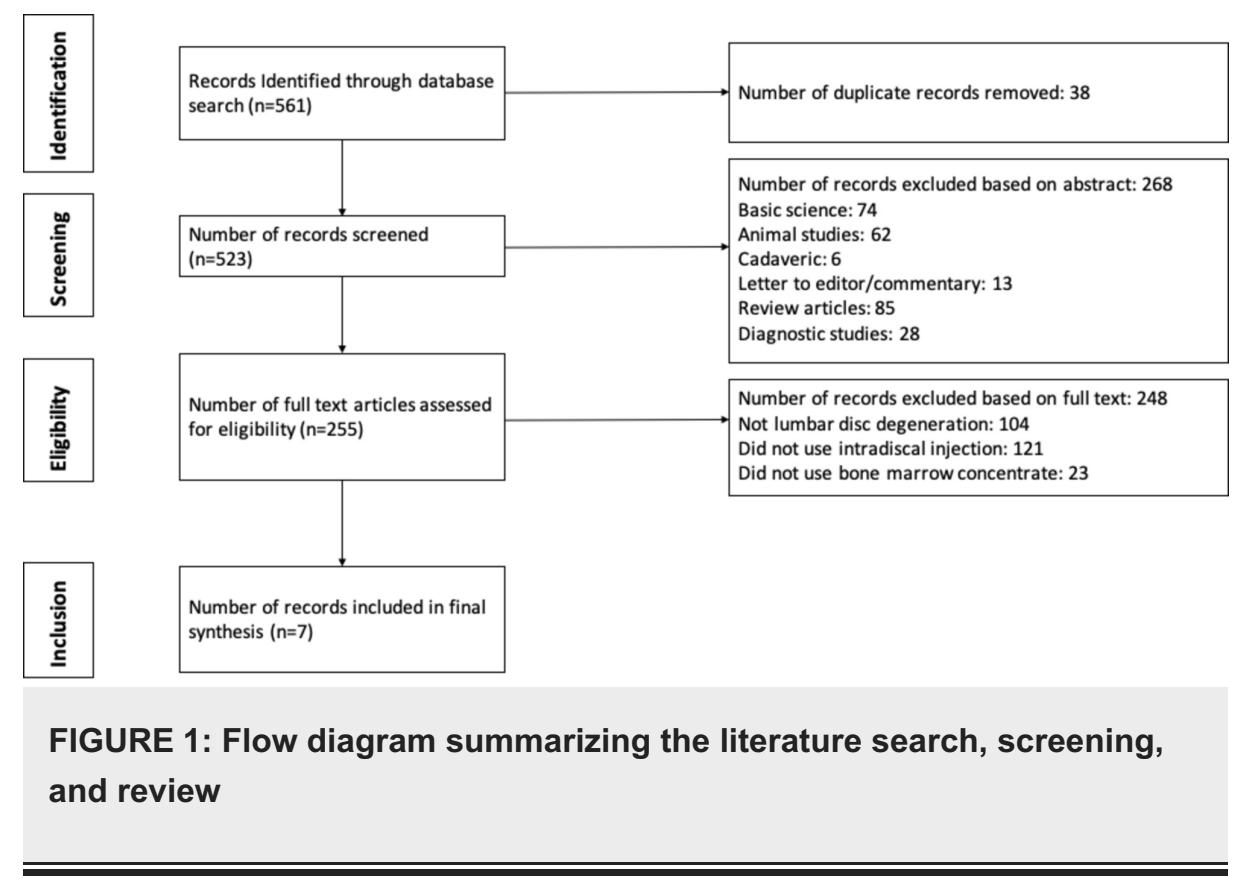

Two authors independently reviewed all articles using the methodology recommended by Harris et al. [25]. The study design, patient populations, and procedure technique were first identified. All lower back-specific patient-reported outcome scores, re-injection rates, and complication rates were analyzed.

The levels of evidence were then assigned based on the Oxford Centre for Evidence-Based Medicine [26]. Study methodological quality was analyzed using the Modified Coleman Methodology Score (MCMS) and was considered good with scores between 70 and 84, fair with scores between 55 and 69, and poor with scores less than 55 [27]. Based on the quality of the evidence, the overall strength-of-recommendation taxonomy (SORT) and grading of recommendations assessment, development and evaluation (GRADE) scores were provided [28-29]. Study heterogeneity and nature of evidence (mostly retrospective, non-comparative) precluded meta-analysis. Thus, a best-evidence synthesis was used instead [30]. Only the outcome measurements used by $50 \%$ or more of the studies were included in the data synthesis to increase the power of the measurement over that of individual studies. A weighted mean of pre-injection and post-injection values from each study were calculated and comparisons were made using two-sample Z-tests using a pvalue of less than 0.05 for significance. 


\section{Results}

Seven articles were analyzed (Table 1) [31-37]. Six articles were level IV evidence and one article was level II. Three studies were performed in the United States and two studies each were performed in Japan and Spain. According to MCMS, one article was good, four articles were fair, and two articles were poor. The mean MCMS was $56.6 \pm 9.1$. The overall SORT score was B and the GRADE score was C. There was a total of 97 patients analyzed. There were 47 males, 38 females, and 12 unspecified genders. The mean age was $33.9 \pm$ 14.3 years old, with a mean follow-up of $44.4 \pm 25.4$ months. BMC was obtained by centrifugation of 30 to 90 $\mathrm{mL}$ of autologous (six studies) bone marrow aspiration from the iliac crest or posterior superior iliac spine (PSIS) to perform a fluoroscopy-guided injection of 2 to $3 \mathrm{~mL}$ of BMC directly into one or more symptomatic intervertebral discs. The estimated number of MSCs injected per disc ranged from $1 \times 10^{6}$ to $3.6 \times 10^{8}$ cells.

\begin{tabular}{|c|c|c|c|c|c|c|c|}
\hline Study & Orozco et al. 2011 & $\begin{array}{l}\text { Yoshikawa et al. } \\
2010\end{array}$ & $\begin{array}{l}\text { Pettine et al. } \\
2017\end{array}$ & $\begin{array}{l}\text { Mochida et al. } \\
2015\end{array}$ & Noriega et al. 2017 & $\begin{array}{l}\text { Centeno et } \\
\text { al. } 2017\end{array}$ & Elabd et al. 2016 \\
\hline Type of study & Case Series & Case Series & Case Series & Case Series & $\begin{array}{l}\text { Prospective } \\
\text { randomized control } \\
\text { study }\end{array}$ & Case Series & Case Series \\
\hline $\begin{array}{l}\text { Level of } \\
\text { evidence }\end{array}$ & IIA & IV & IV & IV & II & IV & IV \\
\hline Country & Spain & Japan & USA & Japan & Spain & USA & USA \\
\hline No. subjects & 10 & 2 & 26 & 9 & 12 & 33 & 5 \\
\hline Gender (M/F) & $4 / 6$ & $0 / 2$ & $11 / 15$ & $8 / 1$ & NR & $21 / 12$ & $3 / 2$ \\
\hline Age (Mean) & 35 & 68.5 & 40 & 25.7 & NR & 40.3 & 40.4 \\
\hline $\begin{array}{l}\text { Classifications } \\
\text { of degenerative } \\
\text { discs included }\end{array}$ & $\begin{array}{l}\text { Discs with decreased fluid density } \\
\text { with preserved external annulus } \\
\text { fibrosus (Adams stages 2-4) }\end{array}$ & $\begin{array}{l}\text { Discs with } \\
\text { intervertebral } \\
\text { regressive } \\
\text { degeneration and } \\
\text { instability }\end{array}$ & $\begin{array}{l}\text { Modified } \\
\text { Pfirmann } \\
\text { scores 4-7 }\end{array}$ & Pfirrmann grade III & Pfirrmann grades II-IV & $\begin{array}{l}\text { Degenerative } \\
\text { discs with } \\
\text { posterior disc } \\
\text { budge }\end{array}$ & $\begin{array}{l}\text { Degenerative } \\
\text { discs with } \\
\text { posterior disc } \\
\text { bulge } \geq 2 \mathrm{~mm}\end{array}$ \\
\hline Source of BMC & Autologous iliac crest & Autologous iliac crest & $\begin{array}{l}\text { Autologous } \\
\text { iliac crest }\end{array}$ & $\begin{array}{l}\text { Autologous iliac } \\
\text { crest }\end{array}$ & Allogeneic iliac crest & $\begin{array}{l}\text { Autologous } \\
\text { left PSIS }\end{array}$ & $\begin{array}{l}\text { Autologous left } \\
\text { PSIS }\end{array}$ \\
\hline $\begin{array}{l}\text { Amount } \\
\text { injected }\end{array}$ & $\begin{array}{l}5 \times 10^{6} \text { cells per disc from a } \\
\text { suspension containing } 10^{7} \text { cells } / \mathrm{ml}\end{array}$ & $\begin{array}{l}10 \mathrm{ml} \text { of } 10^{5} \mathrm{cells} / \mathrm{ml} \text { in } \\
\text { combination with } \\
\text { collagen sponge }\end{array}$ & $\begin{array}{l}2-3 \mathrm{ml} \text { per } \\
\text { disc; } \\
1.2 \times 10^{8} \text { cells } \\
\text { per } \mathrm{ml}\end{array}$ & $\begin{array}{l}1 \times 10^{6} \text { cells } / 702 \square \mathrm{L} \\
\text { sterile saline per } \\
\text { disc }\end{array}$ & $\begin{array}{l}25 \times 10^{6} \text { cells per disc } \\
\text { from a suspension } \\
\text { containing } 12.5 \mathrm{x} \\
10^{6} \text { cells } / \mathrm{ml}\end{array}$ & $\begin{array}{l}1-3 \mathrm{ml} \text { per } \\
\text { disc; avg } \\
2.3 \times 10^{7} \text { cells } \\
\text { per disc }\end{array}$ & $\begin{array}{l}0.25-1 \mathrm{ml} \text { per } \\
\text { disc; avg } 30.8 \mathrm{x} \\
10^{6} \text { cells per disc }\end{array}$ \\
\hline $\begin{array}{l}\text { Injection } \\
\text { method }\end{array}$ & $\begin{array}{l}\text { Fluoroscopy guided intradiscal } \\
\text { injection }\end{array}$ & $\begin{array}{l}\text { Fluoroscopy guided } \\
\text { intradiscal injection }\end{array}$ & $\begin{array}{l}\text { Fluroscopy } \\
\text { guided } \\
\text { intradiscal } \\
\text { injection }\end{array}$ & $\begin{array}{l}\text { Fluoroscopy } \\
\text { guided intradiscal } \\
\text { injection }\end{array}$ & $\begin{array}{l}\text { Fluoroscopy guided } \\
\text { intradiscal injection }\end{array}$ & $\begin{array}{l}\text { Fluoroscopy } \\
\text { guided } \\
\text { intradiscal } \\
\text { injection }\end{array}$ & $\begin{array}{l}\text { Fluoroscopy } \\
\text { guided } \\
\text { intradiscal } \\
\text { injection }\end{array}$ \\
\hline (months) & 12 & 24 & 36 & 36 & 12 & 72 & 72 \\
\hline Outcomes & ODI, VAS, SF-36 & VAS, JOA & ODI, VAS & $\mathrm{JOA}$ & ODI, VAS, SF-12 & $\begin{array}{l}\text { VAS, FRI, } \\
\text { SANE }\end{array}$ & $\begin{array}{l}\text { QOL } \\
\text { Questionnaire }\end{array}$ \\
\hline
\end{tabular}

\section{TABLE 1: Study demographics}

NR (not recorded); M (male); F (female); BMC (bone marrow concentrate); FRI (functional rating index); SF-36 (36-item short-form health survey); SF12 (12-item short-form health survey); SANE (single assessment numeric evaluation); VAS (visual analog score); ODI (Oswetry disability index); QOL (quality of life); JOA (Japanese Orthopaedic Association scoring system); QOL (quality of life); PSIS (posterior superior iliac spine)

All studies performed intradiscal BMC injections after the failure of non-interventional management. One study used a negative control with a mepivacaine injection, which reported a significant decrease in visual analog score (VAS) and Oswestry disability index (ODI) eight days after the injection as compared to preinjection. However, the study did not report any significant changes in VAS nor ODI at three, six, or 12 months post-injection as compared to pre-injection. No comparison injections were made in any of the other studies. There was one case (1.0\%) of herniated nucleus pulposus (HNP) months post-injection. 
Though no re-injections were performed, six patients (6.2\%) eventually required surgical management due to unresolved pain. No other complications or re-injections were reported (Table 2).

\begin{tabular}{|c|c|c|c|c|c|c|c|c|}
\hline Study & & $\begin{array}{l}\text { Orozco et } \\
\text { al. } 2011\end{array}$ & $\begin{array}{l}\text { Yoshikawa et } \\
\text { al. } 2010\end{array}$ & $\begin{array}{l}\text { Pettine et al. } \\
2017\end{array}$ & $\begin{array}{l}\text { Mochida et } \\
\text { al. } 2015\end{array}$ & $\begin{array}{l}\text { Noriega et } \\
\text { al. } 2017\end{array}$ & $\begin{array}{l}\text { Centeno et } \\
\text { al. } 2017\end{array}$ & $\begin{array}{l}\text { Elabd et al. } \\
2016\end{array}$ \\
\hline \multirow{2}{*}{ SF-36 } & Baseline & $12.7 \pm 3.7$ & NR & NR & NR & NR & NR & NR \\
\hline & Final F/U & $24.8 \pm 3.9$ & NR & NR & NR & NR & NR & NR \\
\hline \multirow{2}{*}{ SF-12 } & Baseline & NR & NR & NR & NR & $46 \pm 3$ & NR & NR \\
\hline & Final F/U & NR & NR & NR & NR & $48 \pm 3$ & NR & NR \\
\hline \multirow{2}{*}{ VAS } & Baseline & $68.9 \pm 3.3$ & NR & $82.1 \pm 2.6$ & NR & $67 \pm 7$ & 52 & NR \\
\hline & Final F/U & $20.0 \pm 6.5$ & 28.0 & $21.9 \pm 4.4$ & NR & $47 \pm 10$ & 20 & NR \\
\hline \multirow{2}{*}{ ODI } & Baseline & $25.0 \pm 4.1$ & NR & $56.7 \pm 3.6$ & NR & $34 \pm 7$ & NR & NR \\
\hline & Final F/U & $7.4 \pm 2.3$ & NR & $17.5 \pm 3.2$ & NR & $22 \pm 7$ & NR & NR \\
\hline \multirow{2}{*}{ JOA } & Baseline & NR & 2.5 & NR & $14.2 \pm 4.8$ & NR & NR & NR \\
\hline & Final F/U & NR & 17.0 & NR & $27.2 \pm 1.6$ & NR & NR & NR \\
\hline \multirow{2}{*}{ FRI } & Baseline & NR & NR & NR & NR & NR & 61 & NR \\
\hline & Final F/U & NR & NR & NR & NR & NR & 12 & NR \\
\hline \multirow{2}{*}{ SANE } & Baseline & NR & NR & NR & NR & NR & 42 & NR \\
\hline & Final F/U & NR & NR & NR & NR & NR & 60 & NR \\
\hline \multirow{2}{*}{ QOL } & Baseline & NR & NR & NR & NR & NR & NR & N/A \\
\hline & Final F/U & NR & NR & NR & NR & NR & NR & $\begin{array}{l}55 \% \\
\text { Improvement }\end{array}$ \\
\hline \multicolumn{2}{|c|}{ Complications } & 0 & 0 & 0 & 0 & 0 & 1 - HNP & 0 \\
\hline \multicolumn{2}{|c|}{ Re-Injection } & 0 & 0 & 0 & 0 & 0 & 0 & 0 \\
\hline \multicolumn{2}{|c|}{$\begin{array}{l}\text { Eventual surgical } \\
\text { management }\end{array}$} & 0 & 0 & 6 & 0 & 0 & 0 & 0 \\
\hline
\end{tabular}

\section{TABLE 2: Individual study outcome measures}

NR (not recorded); F/U (follow-up); SF-36 (36-item short-form health survey); SF-12 (12-item short-form health survey); VAS (visual analog score); ODI (Oswetry disability index); JOA (Japanese Orthopaedic Association scoring system); FRI (functional rating index); SANE (single assessment numeric evaluation); QOL (quality of life); HNP (herniated nucleus pulposus)

Mean VAS decreased by $41.2 \mathrm{~mm}, 45.7 \mathrm{~mm}, 45.1 \mathrm{~mm}$, and $48.8 \mathrm{~mm}$ at three, six, 12, and 24 months following the intradiscal BMC injection, respectively. Mean ODI decreased by 26.9, 27.1, 25.3, and 26.1 at three, six, 12, and 24 months following the intradiscal BMC injection, respectively (Table 3; all $\mathrm{p}<0.001$ vs baseline). 


\section{Cureus}

\begin{tabular}{|c|c|c|}
\hline & VAS (mm) & ODI \\
\hline Baseline & $66.0 \pm 12.3$ & $44.4 \pm 16.3$ \\
\hline 3-month F/U & $24.8 \pm 11.1^{\star}$ & $17.5 \pm 3.5^{\star}$ \\
\hline 6-month F/U & $20.3 \pm 11.4^{*}$ & $17.3 \pm 5.9^{\star}$ \\
\hline 12-month F/U & $20.9 \pm 17.2^{\star}$ & $19.1 \pm 8.5^{\star}$ \\
\hline 24-month $\mathrm{r} / \mathrm{U}$ & $17.2 \pm 8.2^{\star}$ & $\mathrm{NR}$ \\
\hline
\end{tabular}

TABLE 3: Average study outcome measures included in the best-evidence synthesis

NR (not recorded); F/U (follow-up); VAS (visual analog score); ODI (Oswestry disability index); ${ }^{*}<0.001$ vs baseline

\section{Discussion}

This systematic review suggests that intradiscal injection of BMC for lumbar disc degeneration resulted in a statistically significant improvement in VAS and ODI with low re-injection and complication rates for the reported studies. The methodological quality of the studies was fair. To our knowledge, this is the first systematic review to evaluate the outcomes of intradiscal injection of BMC for disc degeneration. The findings were contrary to our expectations.

All studies analyzed utilized intradiscal injection of BMC to treat both the symptoms and the progression of disc degeneration. A study by Pang et al., which was excluded from this review, utilized allogeneic umbilical cord tissue to harvest the MSCs [38]. The authors hypothesized that human umbilical cord tissue-derived mesenchymal stem cells (HUC-MSCs) contain stem cells that can regenerate degenerative discs utilizing the same mechanisms but with additional capacity for localized immunosuppression. This study of two patients resulted in an average VAS and ODI decrease of $50.0 \mathrm{~mm}$ and 38.5, respectively, at the 24-month follow up with no adverse effects.

Surgical rates following intradiscal BMC injection were low (6.2\%) and might be compared to reoperation rates of $9.1 \%$ following spinal fusion or $7.8 \%$ for disc arthroplasty as reported by Jacobs et al. [39]. All six cases requiring eventual surgical management were reported in a single study by Pettine et al., and no other study reported required surgical management [34]. Reported complication rates after BMC injection were low. Besides one case of post-injection disc herniation following treatment, there were no reported adverse effects reported. Again, this complication rate after BMC injection may be compared to $5.0 \%$ in spinal fusions and up to $16.7 \%$ in disc arthroplasty for similar populations [40].

There are several important limitations among the studies included in this review. Six of the seven articles were level IV evidence, which limits the strength of the results [31-36]. None of the studies used a doubleblinded approach, producing potential bias. The average study methodological quality as assessed by the MCMS was fair. The assimilation of heterogeneous low methodological quality studies with VAS and ODI is a significant limitation. We aimed to minimize this as much as possible with strict study eligibility and inclusion criteria, despite the level IV evidence nature of the studies. The heterogeneity of outcome measures used among the studies limited the data analysis to two outcome measures. Additionally, significant heterogeneity in BMC sources (age difference, specifically) may have affected the quality of MSCs. Donor site morbidity may be another limitation that may have led to a lower significant decrease in post-injection pain VAS and ODI. Variable restrictions and regulations among different nations in manipulating MSCs might have also impacted outcomes. Prospective comparative trials, with greater study sizes, using standardized, validated clinical outcome measures are needed.

\section{Conclusions}

Despite our skepticism regarding the efficacy of the procedure, intradiscal injection of BMC for lumbar disc degeneration resulted in a statistically significant improvement in VAS and ODI with low re-injection and complication rates in the studies assessed. Given this study is limited to level IV evidence, the findings suggest that further randomized controlled studies may be worthwhile to evaluate the true efficacy of this treatment.

\section{Additional Information}

\section{Disclosures}

Conflicts of interest: In compliance with the ICMJE uniform disclosure form, all authors declare the following: Payment/services info: All authors have declared that no financial support was received from 
any organization for the submitted work. Financial relationships: Joshua D. Harris declare(s) non-financial support from Arthroscopy. Editorial or governing board. Joshua D. Harris declare(s) non-financial support from American Orthopaedic Society for Sports Medicine. Board or committee member. Joshua D. Harris declare(s) non-financial support from AAOS. Board or committee member. Joshua D. Harris declare(s) a grant from Depuy, A Johnson \& Johnson Company. Research support. Joshua D. Harris declare(s) nonfinancial support from Arthroscopy Association of North America. Board or committee member. Joshua D. Harris declare(s) non-financial support from Frontiers In Surgery. Editorial or governing board. Joshua D. Harris declare(s) personal fees from NIA Magellan. Paid consultant. Joshua D. Harris declare(s) personal fees from SLACK Incorporated. Publishing royalties, financial or material support. Joshua D. Harris declare(s) personal fees from Smith \& Nephew. Paid consultant; Paid presenter or speaker; Research support. Joshua D. Harris declare(s) personal fees from Ossur. Paid speaker. Other relationships: All authors have declared that there are no other relationships or activities that could appear to have influenced the submitted work.

\section{References}

1. Andersson GB: Epidemiological features of chronic low-back pain . Lancet. 1999, 354:581-585. 10.1016/S0140-6736(99)01312-4

2. Frank JW, Brooker AS, DeMaio SE, et al.: Disability resulting from occupational low back pain. Part I: what do we know about primary prevention? A review of the scientific evidence on prevention before disability begins. Spine. 1996, 21:2908-2917. 10.1097/00007632-199612150-00024

3. Battie MC, Videman T, Parent E: Lumbar disc degeneration: epidemiologic and genetic influences . Spine. 2004, 29:2679-2690. 10.1097/01.brs.0000146457.83240.eb

4. Derby R, Kim BJ, Lee SH, Chen Y, Seo KS, Aprill C: Comparison of discographic findings in asymptomatic subject discs and the negative discs of chronic LBP patients: can discography distinguish asymptomatic discs among morphologically abnormal discs?. Spine J. 2005, 5:389-394. 10.1016/j.spinee.2005.01.007

5. Balagué F, Mannion AF, Pellisé F, Cedraschi C: Clinical update: low back pain. Lancet. 2007, 369:726-728. 10.1016/S0140-6736(07)60340-7

6. Buser Z, Ortega B, D’Oro A, et al.: Spine degenerative conditions and their treatments: national trends in the United States of America. Global Spine J. 2018, 8:57-67. 10.1177/2192568217696688

7. Croft PR, Macfarlane GJ, Papageorgiou AC, Thomas E, Silman AJ: Outcome of low back pain in general practice: a prospective study. BMJ. 1998, 316:1356-1359. 10.1136/bmj.316.7141.1356

8. Pengel LH, Herbert RD, Maher CG, Refshauge KM: Acute low back pain: systematic review of its prognosis . BMJ. 2003, 327:323. 10.1136/bmj.327.7410.323

9. Vroomen PC, de Krom MC, Slofstra PD, Knottnerus JA: Conservative treatment of sciatica: a systematic review. J Spinal Disord. 2000, 13:463-469. 10.1097/00002517-200012000-00001

10. Luijsterburg PA, Verhagen AP, Ostelo RW, van Os TA, Peul WC, Koes BW: Effectiveness of conservative treatments for the lumbosacral radicular syndrome: a systematic review. Eur Spine J. 2007, 16:881-899. 10.1007/s00586-007-0367-1

11. Turner JA, Ersek M, Herron L, Haselkorn J, Kent D, Ciol MA, Deyo RA: Patient outcomes after lumbar spinal fusions. JAMA. 1992, 268:907-911. 10.1001/jama.1992.03490070089049

12. Deyo RA, Cherkin DC, Loeser JD, Bigos SJ, Ciol MA: Morbidity and mortality in association with operations on the lumbar spine: The influence of age, diagnosis and procedure. J Bone Joint Surg Am. 1992, 74:536543.

13. Deyo RA, Mirza SK, Martin BI, Kreuter W, Goodman DC, Jarvik JG: Trends, major medical complications, and charges associated with surgery for lumbar spinal stenosis in older adults. JAMA. 2010, 303:1259-1265. 10.1001/jama.2010.338

14. Rajaee SS, Bae HW, Kanim LE, Delamarter RB: Spinal fusion in the United States: analysis of trends from 1998 to 2008. Spine. 2012, 37:67-76. 10.1097/BRS.0b013e31820cccfb

15. Mannion AF, Fekete TF, O'Riordan D, et al.: The assessment of complications after spine surgery: time for a paradigm shift?. Spine J. 2013, 13:615-624. 10.1016/j.spinee.2013.01.047

16. Basso M, Caagnaro L, Zanirato A, Divano S, Formica C, Formica M, Felli L: What is the clinical evidence on regenerative medicine in intervertebral disc degeneration?. Musculoskelet Surg. 2017, 101:93-104. 10.1007/s12306-017-0462-3

17. Le Maitre CL, Baird P, Freemont AJ, Hoyland JA: An in vitro study investigating the survival and phenotype of mesenchymal stem cells following injection into nucleus pulposus tissue. Arthritis Res Ther. 2009, 11:R20. 10.1186/ar2611

18. Dragoo JL, DeBaun MR: Stem cell yield after bone marrow concentration . Orthop J Sports Med. 2017, $21: 10.1177 / 2325967117 \mathrm{~s} 00445$

19. Hohaus C, Ganey TM, Minkus Y, Meisel HJ: Cell transplantation in lumbar spine disc degeneration disease . Eur Spine J. 2008, 17:492-503. 10.1007/s00586-008-0750-6

20. Hiyama A, Mochida J, Iwashina T, et al.: Transplantation of mesenchymal stem cells in a canine disc degeneration model. J Orthop Res. 2008, 26:589-600. 10.1002/jor.20584

21. Henriksson HB, Svanvik T, Jonsson M, Hagman M, Horn M, Lindahl A, Brisby H: Transplantation of human mesenchymal stems cells into intervertebral discs in a xenogeneic porcine model. Spine. 2009, 34:141-148. 10.1097/BRS.0b013e31818f8c20

22. Sakai D, Mochida J, Iwashina T, Watanabe T, Nakai T, Ando K, Hotta T: Differentiation of mesenchymal stem cells transplanted to a rabbit degenerative disc model: Potential and limitations for stem cell therapy in disc regeneration. Spine. 2005, 30:2379-2387. 10.1097/01.brs.0000184365.28481.e3

23. Moher D, Liberati A, Tetzlaff J, Altman DG, the PRISMA Group: Preferred reporting items for systematic reviews and meta-analyses: the PRISMA statement. PLoS Med. 2009, 6:e1000097. 10.1371/journal.pmed.1000097

24. CEBM. Levels of evidence: introductory document . (2011). Accessed: April 20, 2020: https://www.cebm.net/2011/06/2011-oxford-cebm-levels-evidence-introductory-document/. 
25. Harris JD, Quatman CE, Manring MM, Siston RA, Flanigan DC: How to write a systematic review. Am J Sports Med. 2014, 42:2761-2768. 10.1177/0363546513497567

26. 2011 Oxford CEBM evidence. (2011). Accessed: April 22, 2020: http://www.cebm.net/index.aspx?o1/45653.

27. Coleman B, Khan K, Maffulli N, Cook J, Wark J: Studies of surgical outcome after patellar tendinopathy: clinical significance of methodological deficiencies and guidelines for future studies. Scand J Med Sci Sports. 2000, 10:2-11. 10.1034/j.1600-0838.2000.010001002.x

28. Ebell MH, Siwek J, Weiss BD, Woolf SH, Susman J, Ewigman B, Bowman M: Strength of Recommendation Taxonomy (SORT): a patient-centered approach to grading evidence in the medical literature. Am Fam Physician. 2004, 69:549-557.

29. GRADE working group. (2000). Accessed: April 24, 2020: https://www.gradeworkinggroup.org.

30. Slavin RE: Best evidence synthesis: an intelligent alternative to meta-analysis. J Clin Epidemiol. 1995, 48:918. 10.1016/0895-4356(94)00097-a

31. Mochida J, Sakai D, Nakamura Y, Watanabe T, Yamamoto Y, Kato S: Intervertebral disc repair with activated nucleus pulposus cell transplantation: a three-year, prospective clinical study of its safety. Eur Cell Mater. 2015, 29:202-212. 10.22203/ecm.v029a15

32. Orozco L, Soler R, Morera C, Alberca M, Sanchez A, Garcia-Sancho J: Intervertebral disc repair by autologous mesenchymal bone marrow cells: a pilot study. Transplantation. 2011, 92:822-828. 10.1097/TP.0b013e3182298a15

33. Yoshikawa T, Ueda Y, Miyazaki K, Koizumi M, Takakura Y: Disc regeneration therapy using marrow mesenchymal cell transplantation: a report of two case studies. Spine. 2010, 35:475-480. 10.1097/BRS.0b013e3181cd2cf4

34. Pettine KA, Suzuki RK, Sand TT, Murphy MB: Autologous bone marrow concentrate intradiscal injection for the treatment of degenerative disc disease with three-year follow up. Int Orthop. 2017, 41:2097-2103. 10.1007/s00264-017-3560-9

35. Centeno C, Markle J, Dodson E, et al.: Treatment of lumbar degenerative disc disease-associated radicular pain with culture-expanded autologous mesenchymal stem cells: a pilot study on safety and efficacy. J Transl Med. 2017, 15:197. 10.1186/s12967-017-1300-y

36. Elabd C, Centeno CJ, Schultz JR, Lutz G, Ichim T, Silva FJ: Intra-discal injection of autologous, hypoxic cultured bone marrow-derived mesenchymal stem cells in five patients with chronic lower back pain: a long-term safety and feasibility study. J Transl Med. 2016, 14:253. 10.1186/s12967-016-1015-5

37. Noriega DC, Ardura F, Hernandez-Ramajo R, et al.: Intervertebral disc repair by allogeneic mesenchymal bone marrow cells: a randomized controlled trial. Transplantation. 2017, 101:1945-1951. 10.1097/TP.0000000000001484

38. Pang X, Yang H, Peng B: Human umbilical cord mesenchymal stem cell transplantation for the treatment of chronic discogenic low back pain. Pain Physician. 2014, 17:525-530.

39. Jacobs W, Van der Gaag NA, Tuschel A, de Kleuver M, Peul W, Verbout AJ, Oner FC: Total disc replacement for chronic back pain in the presence of disc degeneration. Cochrane Database Syst Rev. 2012, 9:CD008326. 10.1002/14651858.CD008326.pub2

40. Formica M, Divano S, Cavagnaro L, Marco Basso M, Zanirato A, Formica C, Felli L: Lumbar total disc arthroplasty: outdated surgery or here to stay procedure? A systematic review of current literature. J Orthop Traumatol. 2017, 18:197-215. 10.1007/s10195-017-0462-y 